\title{
Recent shifts in Daphnia community structure in southeastern Lake Michigan: A comparison of the inshore and offshore regions ${ }^{1,2}$
}

\author{
Marlene S. Evans and David J. Jude \\ Great Lakes Research Division, University of Michigan, Ann Arbor 48109
}

\begin{abstract}
Before 1982, Daphnia retrocurva and Daphnia galeata mendotae were the dominant species of Daphnia in Lake Michigan. Between 1972 and 1981, Daphnia community structure in the offshore region shifted toward greater dominance of the larger D. galeata mendotae, with Daphnia pulicaria, another large species, dominating by 1982 . This continued through summer 1984. Shifts in offshore Daphnia community structure appear to be related to a reduction in predation pressure by declining alewife (Alosa pseudoharengus) populations and a hypothesized increase in relative predation pressure by Mysis relicta. From 1972 to 1984, Daphnia community structure changed only slightly in the inshore region; $D$. retrocurva generally remained the summer and autumn dominant. However, summer Daphnia abundances decreased after 1980 as yellow perch (Perca flavescens) and bloater (Coregonus hoyi) increased. From an examination of historic data we conclude that inshore region Daphnia populations probably have changed little since the late 1880s. The 1982-1984 offshore Daphnia complex, however, differed markedly from the earliest (mid-1950s) record of zooplankton community structure in this region of southeastern Lake Michigan.
\end{abstract}

Lake Michigan, like the other Laurentian Great Lakes, has been exposed to various disturbances over the last several decades (Beeton 1969), including eutrophication, habitat alteration, sea lamprey predation (Petromyzon marinus), and invasion of exotics such as the alewife (Alosa pseudoharengus) (Damann 1960; Wells and McLain 1972; Christie 1974). With no significant predation by the reduced lake trout ( $\mathrm{Sal}$ velinus namaycush) populations, and with reduced competition from lowered populations of endemic planktivores, the planktivorous alewife rapidly dominated the Lake Michigan fish community (Christie 1974). Furthermore, zooplankton community structure apparently was altered as a consequence of eutrophication and the alewife population explosion (Brooks 1969; Wells 1970; McNaught 1975).

During the late 1960s and 1970s, programs were instituted to slow eutrophication, utilize alewife populations, and restore the commercial fisheries. As part of the fisheries management program, the lakes were stocked with lake trout and other salmonids, species which thrive in clean, oligo-

\footnotetext{
${ }^{1}$ Indiana \& Michigan Electric Company and Michigan Sea Grant provided support for the study.

2 Great Lakes Research Division, University of Michigan, contribution 423.
}

trophic waters (Smith 1972). Stocking has been highly successful; an economically valuable salmonid fishery has been produced and alewife populations have been more efficiently managed. Stewart et al. (1981) suggested that if salmonids and lake trout became too abundant, they would begin to deplete their alewife forage base. This in turn might affect the zooplankton community.

Recently, Daphnia populations in southeastern Lake Michigan have changed dramatically in different ways in the inshore and offshore regions, while alewife abundances declined in both regions. Concurrently, abundances of bloaters (Coregonus hoyi), primarily an open-lake, deep-water species, and yellow perch (Perca flavescens), an inshore species, increased (Jude and Tesar 1985; Wells and Hatch unpubl.). Here we report changes in the Daphnia community between 1972 and 1984 and examine the long term relationship among Daphnia species assemblages and alewife, bloater, and yellow perch populations. We then re-examine the current understanding of long term (1887 to the late 1960s) changes in Lake Michigan zooplankton community structure.

The NOAA Great Lakes Environmental Research Laboratory, Ann Arbor, provided ship time in 1982. Internal reviewers were 
C. Schelske, E. Stoermer, and G. Warren: M. Sweeney drafted the figures. Special thanks are extended to an anonymous reviewer.

\section{Methods}

Zooplankton was collected every month from April through October from 1972 to May 1982 over a 14-30-station survey grid (Fig. 1) extending $11 \mathrm{~km}$ north and south and $11 \mathrm{~km}$ offshore of the Donald C. Cook Nuclear Power Plant (Bridgman, Michigan). In some years, samples also were collected in November and December. Station depths generally ranged from 4 to $40 \mathrm{~m}$. A $50-\mathrm{cm}$-diameter net of $156-\mu \mathrm{m}$ mesh equipped with a calibrated flowmeter was used to collect zooplankton. Beginning in 1975, zooplankton also was collected monthly (January-December) in the cooling waters of the power plant. Although this aspect of the study also terminated in May 1982 , some samples were collected in summer 1982, 1983, and 1984, and in autumn 1982. Intake sampling provides estimates of zooplankton abundances in the inshore region (Evans and Flath 1984).

In 1982, a series of zooplankton samples was collected each month from April to October, and in July, August, and late September 1984, at 100-m-deep station 7 (Fig. 1), $20 \mathrm{~km}$ offshore of Grand Haven. Zooplankton was collected during the day by hauling the 50-cm-diameter, $156-\mu \mathrm{m}$-mesh net from $50 \mathrm{~m}$ to the surface.

We did not collect zooplankton at station 7 in 1983 nor are published data available for this region of the lake for 1983. However, Schulze (1984) investigated zooplankton depth distributions in July and August 1983 at station $S$ in $100 \mathrm{~m}$ of water in southwestern Lake Michigan at a latitude similar to our station 7 (Fig. 1). Average 0-40-m water column abundances for Daphnia pulicaria and Daphnia galeata mendotae were calculated from his figures 19 and 20 and from data in his appendix. Daphnia retrocurva abundances were calculated from data for the entire water column (see appendix: Schulze 1984); we use an estimated correction factor of 1.6 to express these $0-90-\mathrm{m}$ data as $0-40-\mathrm{m}$ water column averages.

Daphnia species were identified from

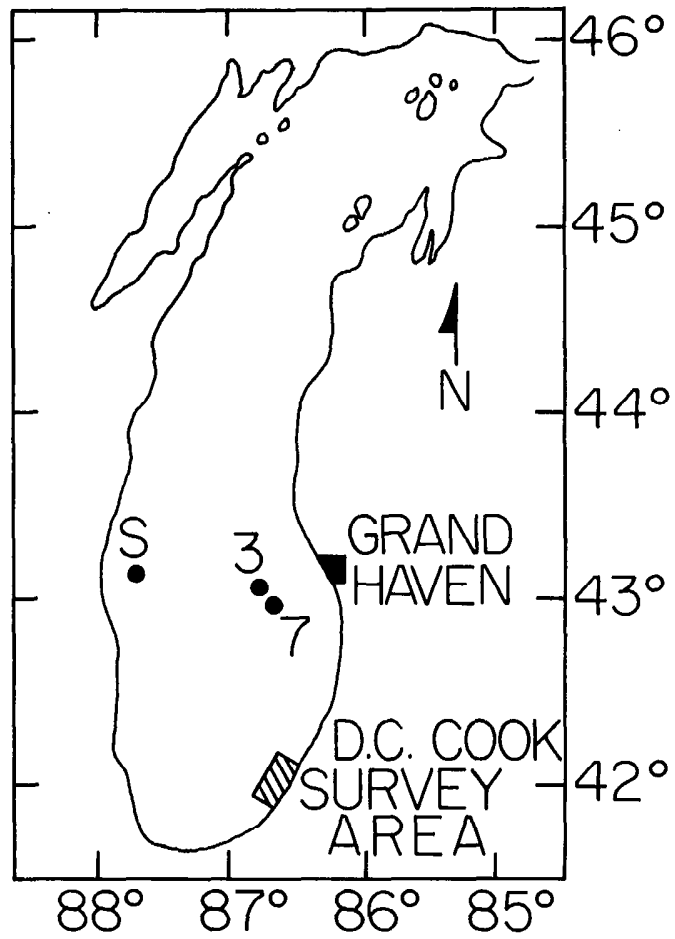

Fig. 1. Map of Lake Michigan showing location of the survey area and 100-m stations 3 and 7. (Station S from Schulze 1984, in 1983.)

Brooks (1957, 1959), Brandlova et al. (1972), and Grogg (1977) (see also Evans 1985). Futher information on sampling and laboratory procedures has been provided by Evans et al. $(1980,1982)$.

Fish were collected in the inshore region monthly from April to November (1973 to 1982) with two types of gear, nylon experimental gill nets and duplicate bottom trawls, at 6- and 9-m stations offshore from the Cook power plant and at a similar transect $8 \mathrm{~km}$ south of the plant, during the day and night. Further information on field and laboratory procedures is given elsewhere (Jude et al. 1979; Jude and Tesar 1985).

\section{Results}

New occurrence of Daphnia pulicariaBefore 1978 only two species of Daphnia, D. galeata mendotae and D. retrocurva, were found in the power plant study area (max depth $40 \mathrm{~m}$ ). In October and November 1978, D. pulicaria was observed for the first time. Abundances were low $\left(<30 \mathrm{~m}^{-3}\right)$ 

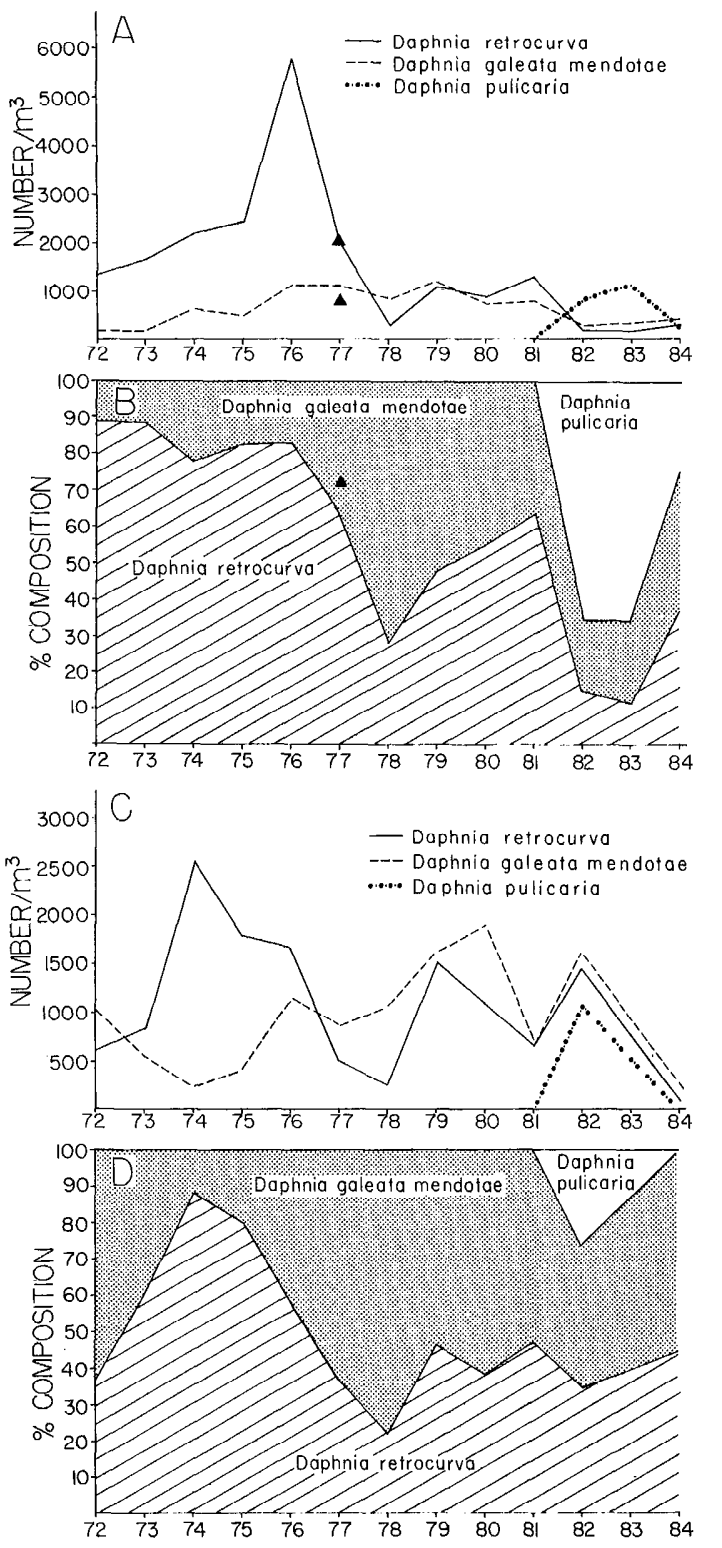

Fig. 2. Daphnia abundance and composition in the offshore region of southern Lake Michigan. A,B. Summer (July-August average) for the 1972-1984 period. C,D. Autumn (October) for the 1972-1984 period. Also shown is summer Daphnia community structure at 100-m station 3 (A). Details given in text.

through early 1982 , accounting for $<0.1 \%$ of the numerical standing stock of crustacean zooplankton.

Daphnia pulicaria was not seen in the deeper waters $(100 \mathrm{~m})$ in collections made at the $100-\mathrm{m}$ station 3 (Fig. 1) in July and
August 1977 by Evans (unpubl.), at station 7 (Fig. 1) by H. A. Vanderploeg (unpubl.) in June and July 1978 , or those made by Evans (unpubl.) in May, August, and September 1979, and in May, July, and August 1981. It was not present in April and May 1982 collections at station 7 but was abundant through the rest of that year, with a maximum of 954 animals $\mathrm{m}^{-3}$ in July. This species was also abundant in August 1983 and July and August 1984.

Long term trends in Daphnia community structure-Data from the 30-40-m depth region of the power plant study area provide the best estimate of Daphnia community structure in the offshore region. In 1977, Daphnia abundances and composition were similar (July-August average) at 100-m station 3 and in the 30-40-m depth region (Fig. $2 \mathrm{~A}, \mathrm{~B})$, suggesting that the deepest region of the study area does provide a reasonable estimate of offshore daphnid population characteristics.

The summer (July-August average) abundances and composition (Fig. 2A,B) of the offshore daphnid assemblage shifted from a 1972-1976 community strongly dominated by the small $D$. retrocurva, to a 1977-1981 community strongly dominated by the larger $D$. galeata mendotae, to a $1982-$ 1984 community strongly dominated by the very large $D$. pulicaria.

Autumn data (October) showed a somewhat similar pattern (Fig. 2C,D). Because the 30-40-m depth was not sampled in 1975 and 1976 due to inclement weather, we show data from 20 to $30 \mathrm{~m}$. Daphnia galeata mendotae decreased between 1972 and 1974 while $D$. retrocurva increased. However, as in summer (Fig. 2A,B), D. galeata mendotae increased in both abundance and percentage from 1974 to 1981. Daphnia pulicaria was a significant component of the 1982 offshore daphnid assemblage but declined in 1984.

Daphnia retrocurva was more strongly dominant in the inshore than in the offshore region (Fig. 3A,B). There were no major changes in its dominance inshore from 1972-1984. Daphnia in general was scarce in summer from 1981 to 1984 , averaging $9 \%$ of the 1972-1980 mean value.

The inshore and offshore regions contin- 

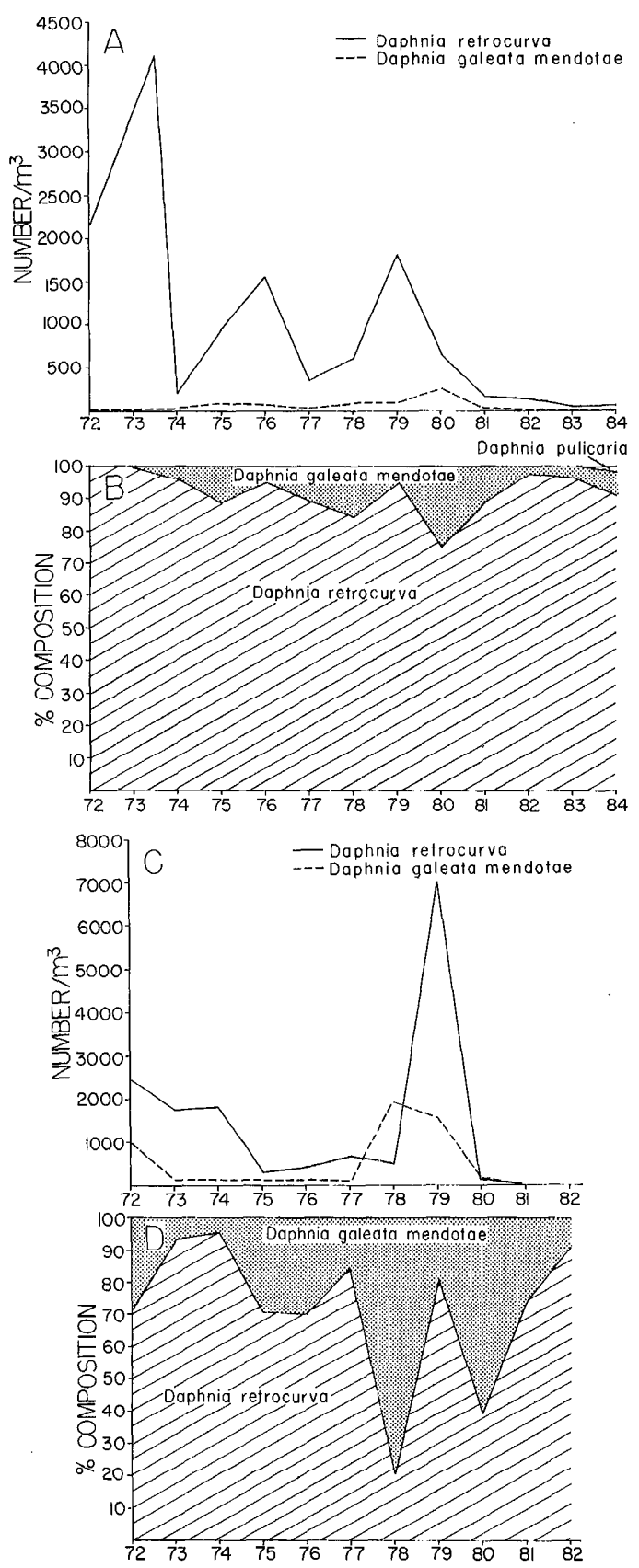

Fig. 3. Daphnia abundance and composition in the inshore region (5-10-m depth contour) in southeastern Lake Michigan. A,B. Summer (July-August average) for the 1972-1984 period. C,D. Autumn (October) for the 1972-1982 period. Details given in text.
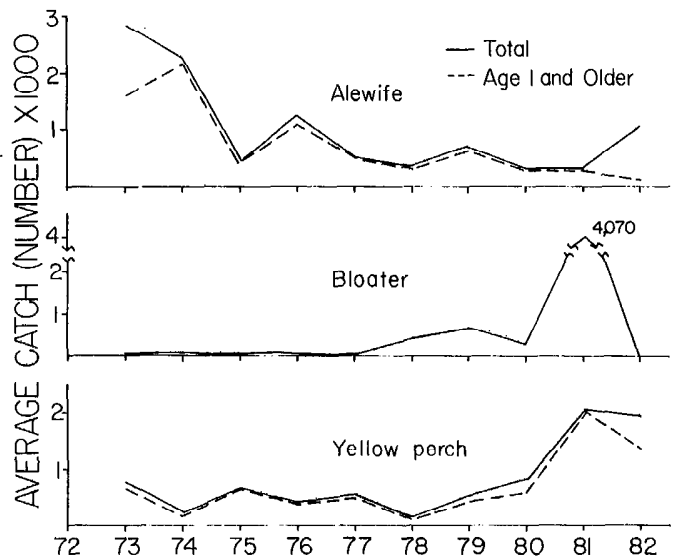

Fig. 4. Average summer (July-August) catch (trawls and gill nets) of alewife (Alosa pseudoharengus), bloater (Coregonus hoyi), and yellow perch (Perca flavescens) in the inshore region (5-10-m depth) for the 19731982 period.

ued to differ through autumn, with the relatively small $D$. retrocurva a much stronger dominant inshore than offshore (Fig. 3C,D). However, there were no consistent changes in its autumn dominance from 1972-1982. Daphnia was scarce in the inshore region during the 1981-1982 period, averaging only $1 \%$ of the 1972-1980 value.

Long term trends in alewife, bloater, and yellow perch abundances-During summer (July-August average), trawl and gill net collections made inshore from 5 to $10 \mathrm{~m}$ were dominated by age 1 and older fish (Fig. 4); young-of-the-year were too small to be effectively captured this way. Age 1 and older alewives showed a steady decrease between 1973 and 1982. Young-of-the-year were more common in trawl and gill net collections in summer 1982 than in earlier summers, except for 1973. Yellow perch, the second-most abundant planktivore in the early 1970 s, changed little in abundance between 1973 and 1979 and then increased between 1980 and 1982 . There were more young-of-the-year in summer 1982 than in earlier years. Bloaters remained more or less steady between 1973 and 1977 and then increased between 1978 and 1981; catches were lower in summer 1982.

With autumn cooling, alewives, yellow perch, and bloaters migrated to deeper regions of the lake. Age 1 and older accounted 


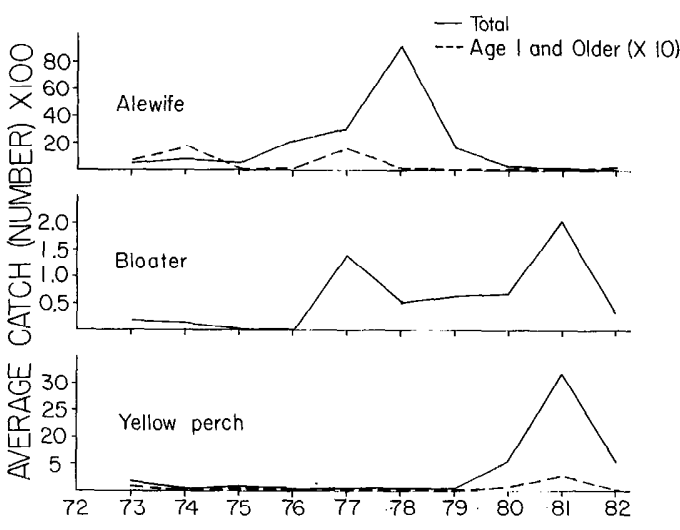

Fig. 5. As Fig. 4, but of average autumn (October) catch. Abundances of age 1 and older alewives are multiplied by a factor of 10 .

for only a small fraction of the gill net and trawl catch from the inshore region, as they migrated offshore earlier than young-of-theyear (Fig. 5). Young-of-the-year alewives and yellow perch were collected in higher numbers in autumn than in summer because they were large enough and had moved from their shallow $(<5 \mathrm{~m})$ summer nursery grounds. As in summer, age 1 and older alewives decreased in abundance over 19731982. Fewer young-of-the-year alewives were collected in the inshore region after 1979 along with increasing numbers of yellow perch, especially young-of-the-year. Bloaters were a minor component of the autumn fish assemblage of the inshore region, with juveniles and adults predominating. Abundances were low over 19731976 but were consistently higher in later years.

A second way to examine long term trends in fish populations in the inshore region is to consider total annual catch; to some extent, this compensates for seasonal variability. Three periods can be considered: 1973-1977, when $D$. retrocurva and $D$. galeata mendotae were the only two daphnids detected in the plankton; 1978-1981, when D. pulicaria appeared sporadically; and 1982 when $D$. pulicaria became dominant in summer and autumn offshore. Total alewife catches in gill nets and trawls decreased between the 1973-1977 and the 1978-1981 period. Average catches of juveniles and
Table 1. Total annual catch (gill nets and trawls) of alewives, bloaters, and yellow perch in the inshore region (Cook power plant study area) of southeastern Lake Michigan by time period. Further explanation given in text.

\begin{tabular}{crr}
\hline \hline Time period & Age 1 and older & \multicolumn{1}{c}{ Total } \\
\hline Alewife & & \\
$1973-1977$ & 10,913 & 13,966 \\
$1978-1981$ & 5,176 & 8,631 \\
1982 & 1,529 & 3,600 \\
Bloater & & \\
$1973-1977$ & 86 & 122 \\
$1978-1981$ & 3,726 & 4,128 \\
1982 & 1,360 & 1,394 \\
Yellow perch & & \\
$1973-1977$ & 1,822 & 2,075 \\
$1978-1981$ & 6,003 & 7,349 \\
1982 & 8,920 & 12,292 \\
\hline
\end{tabular}

adults were further reduced in 1982-only about $14 \%$ of the $1973-1977$ mean value (Table 1). Bloater catches increased between the 1973-1977 and the 1978-1981 periods but were lower in 1982. Yellow perch catches increased severalfold as alewife catches declined. In 1982, the proportion contributed by young-of-the-year to the total gill net and trawl annual catch increased markedly for yellow perch and alewives.

\section{Discussion}

Long term trends in alewife abundances: 1973-1984-During the last two decades, the dominant Lake Michigan planktivore has been the alewife (Wells 1970; Christie 1974; Hatch et al. 1981; Stewart et al. 1981). Adults migrate inshore in spring, spawning in June and July. During summer, youngof-the-year inhabit the nearshore epilimnion and yearlings the thermocline, while adults are found in and below the thermocline. Alewife feeding behavior varies as a function of size and distribution. In the inshore region, immature and adult alewives are planktivorous, while in deep waters, small $(<120 \mathrm{~mm})$ alewives feed on microcrustaceans and adults feed more heavily on the epibenthic Mysis relicta (an omnivorous mysid) and the benthic Pontoporeia hoyi (a detritus-feeding amphipod) (Morsell and Norden 1968; Janssen and Brandt 1980; Wells 1980). As a consequence of regional 
variations in alewife abundance and feeding behavior, predation pressure on the zooplankton community varies spatially. The dominance of the summer and autumn inshore zooplankton community by small animals has been related to relatively intense fish predation pressure in these nearshore waters (Hawkins and Evans 1979; Evans et al. 1980).

Alewife abundances (especially juveniles and adults) declined in the inshore region between 1973 and 1982 (Figs. 4, 5; Table 1; Jude and Tesar 1985). Since a similar trend was observed by U.S. Fish and Wildlife Service personnel in their annual, lake-wide, autumn census (Wells and Hatch unpubl.), our studies in the inshore region of the Cook power plant apparently represent estimates of lake-wide, long term trends.

In the power plant study area, larger numbers of young-of-the-year alewives were gillnetted and trawled in summer 1982 than in earlier years (Fig. 4; Table 1). However, Wells and Hatch (unpubl.) did not observe an increase in young-of-the-year in autumn 1982. In summer 1982 fewer young-of-theyear alewives were collected in beach seines than in earlier years (Tesar and Jude 1985). This suggests that in summer 1982 youngof-the-year alewives were displaced offshore from their shallow nursery grounds, possibly by the large population of young-of-theyear yellow perch. Crowder and Magnuson (1982) reported autumn displacement of alewives by increased bloater populations.

Juvenile and adult alewives continued to decrease after 1982. Wells and Hatch (unpubl.) reported that the 1983 autumn catch of age 1 and older alewives was only 12\% of the 1981 catch. Alewife abundances remained low in autumn 1984 and 1985 ( $\mathrm{L}$. Wells pers. comm.).

Long term trends in the offshore Daphnia community - Wells (1970) found large changes in the summer zooplankton community structure in the offshore waters of Lake Michigan in 1954, when alewife abundances were low, and in 1966, at the height of the alewife population explosion. The initial changes which we observed in the offshore Daphnia community were subtle. The first, between 1972 and 1978, was an increase in dominance of the larger $D$. galeata mendotae over the smaller $D$. retrocurva. Between 1978 and 1981, the most striking change was the sporadic appearance of the very large $D$. pulicaria (mean dry wt, 13.1 $\mu \mathrm{g}$ : M. Evans unpubl. data) in the plankton. Secondly, D. galeata mendotae and $D$. retrocurva increased in size. The mean August-October dry weight of $D$. galeata mendotae increased from $2.5-3.8 \mu \mathrm{g}$ in 19751977 to $4.2-7.5 \mu \mathrm{g}$ in 1978-1981; dry weights were not determined before 1975 . Daphnia retrocurva increased from 1.5-2.7 $\mu \mathrm{g}$ to 2.5-3.5 $\mu \mathrm{g}$ over the same periods (M. Evans unpubl. data). Finally, Mesocyclops edax, a relatively large cyclopoid which had been considerably more abundant in the mid-1950s than during and immediately after the alewife population explosion (Wells 1970 ), increased markedly in abundance in autumn 1978 (Evans et al. 1980, 1982); abundances have since remained low (M. Evans unpubl. data).

High size-selective predation pressure exerted by age 1 and older alewives apparently prevented $D$. pulicaria from becoming well established in the deeper offshore waters until 1982, when alewife populations were especially low. Daphnia pulicaria remained abundant in summer 1983 and 1984 as age 1 and older alewife populations remained low. Furthermore, although $D$. retrocurva and $D$. galeata mendotae were not as abundant in 1984 as in earlier years, they were larger, reaching August mean dry weights of 6.4 and $13.2 \mu \mathrm{g}$ and maximum body lengths of 1.82 and $2.42 \mathrm{~mm}$. These maximum lengths exceeded those for $D$. retrocurva $(1.71 \mathrm{~mm})$ and $D$. galeata mendotae $(1.80$ $\mathrm{mm}$ ) collected in summer 1954 during a period of low alewife predation (Wells 1970). This increase in Daphnia body length is consistent with the hypothesis of declining alewife predation.

Bloaters, an important planktivore in the offshore region, increased in abundance through the late 1970s and early 1980s (Jude and Tesar 1985) and continued to increase in 1983 (Wells and Hatch unpubl.) and 1984 (L. Wells pers. comm.) However it is unlikely that these coregonids had as significant an effect on the offshore zooplankton community structure as did alewives. Since bloaters inhabit somewhat cooler waters 
than alewives (Wells 1968), they feed less extensively on epilimnetic and metalimnetic zooplankton, which includes most Daphnia. Large bloaters (>120 mm) feed primarily on $P$. hoyi and $M$. relicta; small bloaters feed on hypolimnetic microcrustaceans, especially Diaptomus spp. and $C y$ clops spp. (Wells and Beeton 1963; Janssen 1978).

Daphnia community structure and mysid predation-In the offshore region, impacts of declines in alewife predation pressure cannot directly account for the decreased summer abundance of the smaller $D$. retrocurva between 1978 and 1982. In offshore Lake Michigan mysids probably are the major invertebrate predators on Daphnia, feeding most efficiently on the smallest animals (Murtaugh 1981a). In the summer Lake Michigan mysids feed preferentially on cladocerans, their selection of prey apparently based on size and shape; the smallest animals are most vulnerable (Bowers and Vanderploeg 1982). Where mysid predation is intense, surviving Daphnia have scarred or incomplete tail spines (Murtaugh 1981b). Although we did not quantify mysid predation, indirect evidence suggests that it was substantial on the offshore Daphnia population. Most larger $(>1.5 \mathrm{~mm})$ and many smaller $D$. pulicaria collected in 1982 had incomplete tail spines (Evans 1985); smaller animals are more likely to be consumed by mysids than to escape with damaged tail spines. Intense alewife predation on the larger $D$. galeata mendotae (and on $M$. relicta) favored the relatively small $D$. retrocurva until about 1977. Then, as alewives declined, predation pressures on $D$. galeata mendotae and mysids were reduced and selection pressures shifted toward species that have the competitive advantage when invertebrate predation is significant and fish predation low: first $D$. galeata mendotae and then the larger $D$. pulicaria.

Numbers of $D$. retrocurva and $D$. galeata mendotae decreased considerably in the offshore region from summer 1982 to summer and autumn 1984: D. pulicaria was less abundant in 1984 than in 1982 and 1983. However, in terms of biomass (mg dry wt $\mathrm{m}^{-3}$ ), Daphnia standing stocks in summers 1983 and 1984 were twofold to threefold those in earlier summers (1975-1982). Furthermore, Daphnia accounted for a much larger percentage of the total dry weight standing stocks of crustacean zooplankton in summer $1983(60 \%)$ and $1984(45 \%)$ than in 1975-1982 (14\%) (Scavia et al. 1986). The decrease in numbers and the increase in biomass of Daphnia occurred as the mean size of individual species of Daphnia increased: that is, the decrease in abundance was most strongly associated with small animals.

Two factors could account for the decreased abundance of small species of Daphnia in 1982, 1983, and 1984: a reduction in birth rates or an increase in death rates. Strong food limitations and competitive interactions among the three daphnid species might have reduced their fecundity in summer 1982-1984 and autumn 1984. However, since Daphnia dominated the summer 1983 and 1984 offshore crustacean biomass, apparently it reproduced well in these years. Conversely, death rates of small Daphnia may have been high, and an increase in the death rates of small Daphnia is consistent with the hypothesis that predation pressure exerted by mysids intensified with the decline in alewives. Small mysids have narrower feeding ranges than large mysids, exerting the most intense predation pressures on the smallest Daphnia (Murtaugh $1981 a$ ). Changes in the abundance or size frequency distribution of mysids may also have affected recent changes in the abundance and mean size of Daphnia. Seasonal and long term trends in cladoceran populations are controlled by many complex interactions involving food level, invertebrate predation, vertebrate predation, and competitive interactions (Goldman et al. 1979; Threlkeld 1979, 1981; Edmondson and Litt 1983) which affect birth and death rates and ultimately species abundance and composition.

Long term trends in mysid populations in Lake Michigan have not been studied. But mysids are an important component of the diet of large alewives in the offshore region (Janssen and Brandt 1980), so their abundance may well have been affected by fluctuations in alewife abundance. Circumstantial evidence supports this hy- 
pothesis. Large ( $>120-140 \mathrm{~mm})$ alewives collected in the mid-1960s near the lake floor at deep $(>25 \mathrm{~m})$ stations had consumed only trace amounts of $M$. relicta: Pontoporeia hoyi was the dominant prey in Morsell and Norden's (1968) study, zooplankton and $P$. hoyi in Wells' (1980) study. However, Janssen and Brandt (1980) found that in 1975 and $1976 \mathrm{M}$. relicta was more common than $P$. hoyi, and in the laboratory alewives had difficulty feeding on $P$. hoyi living in sediments (Janssen 1978). A possible explanation for these differences in feeding habits between the mid-1960s and mid-1970s is that sometime before the height of the alewife population explosion (1966) mysids were severely reduced by alewife predators and larger alewives were forced to consume less preferred prey-the benthic $P$. hoyi and microcrustacean zooplankton. Such a decrease in mysid abundance could account for Wells' (1970) observation that certain species of small zooplankton increased in abundance between 1954 and 1966. Further evidence of a long term decline in mysid populations over the mid-1950s to mid1970 s is provided by Sell (1982), who found that although the annual standing stock of mysids in Lake Michigan in collections made in 1954-1955 and 1975-1976 was similar ( 0.85 and $1.11 \mathrm{~g}$ dry $w t \mathrm{~m}^{-2}$ ), collections made in 1970-1971 averaged only $0.11 \mathrm{~g}$ $\mathrm{m}^{-2}$. Although such a low biomass may have been due in part to the sampling gear used, it is also possible that mysid abundances were depressed as a consequence of earlier alewife predation. Wells (1970) noted that some large zooplankton species had not recovered from the effects of alewife predation two summers after the spring 1967 dieoff. Mysids may have required an even longer recovery time. Preliminary studies suggest that mysids were about $50 \%$ less abundant in summer 1984 than summer 1977 (L. Crowder pers. comm.).

Long term trends in the inshore regionThere were no pronounced shifts in Daphnia community structure in the inshore region but abundances did decline through the early 1980 s. This suggests that size-selective predation pressure by planktivorous fish continued to be important. Since mysids are excluded from the inshore region during summer and autumn by their requirements for cooler waters, it is unlikely that they affected the inshore Daphnia community.

As alewives declined in the inshore region, yellow perch increased (Jude and Tesar 1985). Yellow perch inhabit the warm, inshore waters during summer, gradually migrating offshore in autumn. They spawn in spring and young-of-the-year congregate in shallow $(<5 \mathrm{~m})$ inshore waters until late summer. Long term increases in abundance should affect inshore but not offshore zooplankton communities. Yellow perch increased in abundance between 1980 and 1982 and continued to increase in later years. Wells and Hatch (unpubl.) reported that the 1983 autumn catch was more than 50 times greater than any catch in the last 20 years. Similarly large catches were made in autumn 1984 (L. Wells pers. comm.). Yellow perch are facultative planktivores and can alter Daphnia community structure (Galbraith 1967; Mills and Forney 1983). As yellow-perch increased in the late $1970 \mathrm{~s}$, they no doubt exerted significant predation pressure on the inshore zooplankton. Bloaters, although less abundant inshore than yellow perch, may have had some effect; in shallow waters, they feed on microcrustaceans (Janssen 1978).

Yellow perch and bloaters also may have had a greater effect on the Daphnia community than alewives. Both species are particle feeders and, unlike the filter-feeding alewife, are not well adapted for consuming small zooplankton. By consuming primarily large particles, yellow perch probably exerted greater predation pressure on the large zooplankton, such as Daphnia, and as yellow perch (and bloaters) increased in the inshore region with the alewife population decline, predation pressure on the zooplankton community remained high. Thus Daphnia community structure did not change substantially from 1972 to 1984 .

The exceedingly low numbers of Daphnia in the inshore region over the 1982-1984 period suggest that planktivory was especially intense during these years. Total summer zooplankton abundances were depressed nearly tenfold and small taxa continued to predominate (Evans 1986), suggesting that fish predation rather than 
invertebrate predation or changes in food quantity or quality was the probable cause. In 1983 and 1984, juvenile yellow perch were stunted (L. Wells pers. comm.), suggesting that these fish were food limited, consistent with the major reduction in zooplankton standing stocks.

Other possible factors affecting the Daphnia community-Other environmental factors appear to have had a less significant role in the recent changes in Daphnia community structure. Although blue-green algae (primarily Anacystis incerta and Anabaena flos-aquae) have increased inshore in recent years (Danforth and Ginsberg 1980; Ayers and Feldt 1982; J. C. Ayers unpubl.), Daphnia community structure did not change between 1973 and 1981 and the zooplankton continued to be dominated by small taxa. Nor was there a shift toward a greater dominance of pollution-tolerant species. Overall, it appears unlikely that changes in phytoplankton had a strong effect on Daphnia.

There are no published long term studies of phytoplankton offshore in southern Lake Michigan. The offshore waters have been only slightly affected by eutrophication and in the 1970s were considered at the borderline between oligotrophy and mesotrophy (Chapra and Robertson 1977). Total phosphorus (spring) values near $100-\mathrm{m}$ station 7 have decreased over the last decade, suggesting an improvement in water quality. However, epilimnetic chlorophyll values showed no obvious trend over summer 1976-1984 (Scavia et al. 1986). Slight improvements in water quality per se could not have caused the recent shifts in community structure of offshore Daphnia.

Introduction of Daphnia pulicaria into Lake Michigan waters-Daphnia pulicaria probably was introduced into Lake Michigan from rivers. Daphnia schødleri, a morphological variant of $D$. pulicaria (Grogg 1977), has been found in the eutrophic waters of Lake Winnebago (which discharges into Green Bay, Lake Michigan) and offshore from Milwaukee Harbor (Gannon 1972). Wells (1970) found small numbers of $D$. schødleri in surface tows in 1966 and 1968 along with Scapholeberis, Simocephalus, Alosa (sic, probably Alona), and Moina-genera typically associated with small lakes and ponds. These observations suggest that $D$. pulicaria entered Lake Michigan from inland lakes but that intense fish predation prevented it from becoming well established offshore until 1982 and inshore through summer 1984.

Re-examination of the current understanding of long term changes in the Lake Michigan zooplankton community-Our study suggests that long term (12 years) changes in zooplankton community structure may not occur uniformly in all regions of the lake. In previous studies of long term changes in Lake Michigan zooplankton populations, it was suggested that zooplankton community structure changed dramatically over the last several decades as a consequence of eutrophication and increased abundances of alewives. Some of these purported changes were based on a comparison of Eddy's (1927) collections, made at several shallow-water stations in southern Lake Michigan, and Wells' (1960) collections, made offshore (Brooks 1969). Zooplankton community structure varies with distance offshore, so the evidence for such long term changes is tenuous (Evans et al. 1980). Furthermore, the inshore and offshore regions may react differently to environmental disturbance. Our 12 years of observation both inshore and offshore now allow us to re-examine these historic data to investigate possible changes in Daphnia community structure over the last century.

The earliest southern Lake Michigan zooplankton collections were made inshore by Eddy (1927). In July 1888 , the major cladocerans in the waters off the Chicago breakwater were Bosmina longirostris and Bosmina longispina (now designated Eubosmina longispina: Deevey and Deevey $1971)$. Since $E$. longispina has not been reported from the Great Lakes (Patalas 1972), the two mucronate bosminids observed by Eddy may have been morphological variants of $B$. longirostris. This species continues to be the dominant bosminid in the nearshore waters (Evans et al. 1980). Daphnia was rare in July 1888 collections. Daphnia retrocurva and Daphnia longispina (probably $D$. galeata mendotae: Brooks 1957) were the only two species collected, the former the more common; in July 1927 
$B$. longispina remained the summer dominant while Daphnia was rare or absent (Eddy' 1927).

In the late 1880s (and probably earlier), the inshore region served as a major breeding and nursery ground for several species of fish, many planktivorous at some stage in their life history, including lake whitefish (Coregonus clupeaformis), lake herring (Coregonus artedii), emerald shiner (Notropis atherinoides), and yellow perch (Wells and McLain 1973; Scott and Crossman 1973). This diverse and abundant population of planktivorous fish would have modified the inshore region zooplankton community, leading to a greater dominance of smaller zooplankton. Thus Eddy (1927) saw a cladoceran community where Bosmina was abundant, Daphnia rare, and the smaller $D$. retrocurva predominant-a cladoceran community dominated by small species. Such a community still persists.

The earliest quantitative zooplankton data for the offshore region are from a station 13 $\mathrm{km}$ offshore of Grand Haven in $74 \mathrm{~m}$ of water in 1954 (Wells 1960). In the mid1950 s the alewife population was low, while lake herring populations were high with commercial catches in 1954-1955 similar to those in 1930-1932 (Moffet 1956; Christie 1974). Lake whitefish populations were less abundant than in earlier times; commercial catches were much smaller than in the 1880s and somewhat smaller than in the early 1930s (Wells and McLain 1973). In addition, overfishing and sea lamprey predation had sequentially reduced the sevenspecies complex of coregonids that inhabited the deep water while the smallest species, the bloater, increased (Smith 1964). Thus predation pressure exerted on the offshore zooplankton by indigenous planktivores may have been less intense in the mid1950s than in earlier decades. However, in summer 1954, the mean (mid-July and early August) average density of Daphnia in the upper $40 \mathrm{~m}$ of the water was $2,290 \mathrm{~m}^{-3}$ (calculated from table 4 of Wells 1970). Daphnia retrocurva was the dominant species, accounting for $61 \%$ of the total; $D$. galeata mendotae constituted the remaining 39\%. Although Wells (1970) used a 361$\mu \mathrm{m}$-mesh net, these estimates of Daphnia abundances and composition seem reasonable. Previous studies have shown that 363-, 156-, and 76- $\mu \mathrm{m}$-mesh nets provide similar estimates of Daphnia abundance (Evans and Sell 1985). Thus we can conclude that the Daphnia population in 1954 (pre-alewife) was similar to that in the offshore region in the mid-to-late 1970s when alewives were declining. This suggests that before the alewife invasion indigenous planktivorous fish structured the offshore Daphnia community toward smaller species. That makes the new dominance of $D$. pulicaria during 19821984 even more interesting.

It is tempting to suggest that the recently observed shifts in Daphnia in the offshore region do not represent a return to historic characteristics but rather a new (and possibly unstable) equilibrium in an already highly perturbed system. However, this speculation may be premature. Although $D$. pulicaria was not a significant component of the Great Lakes zooplankton during the 1960s (Patalas 1972) and 1970s, a related species, Daphnia pulex, was abundant in the western basin of Lake Erie in the late 1930s; its abundance has since declined and remains low (Bradshaw 1964; Patalas 1972). According to Chandler (1940), D. pulex attained abundances of up to $3,000 \mathrm{~m}^{-3}$ in western Lake Erie during spring and summer 1939, a period when yellow perch were abundant, although standing stocks of lake herring and lake whitefish were lower than in earlier years (Regier and Hartman 1973). This suggests that under certain conditions large-bodied zooplankton such as $D$. pulicaria can coexist in Great Lakes waters with facultative planktivores. Only examination of the sedimentary record will reveal whether the presence of $D$. pulicaria is a new phenomenon or also occurred in earlier decades during a period of fluctuations iin planktivorous fish abundances.

\section{References}

Ayers, J. C., AND L. E. FeldT. 1982. Phytoplankton of the seasonal surveys of 1978 and 1979, and further pre- vs. post-operational comparisons at the Cook Nuclear Plant. Univ. Mich. Great Lakes Res. Div. Spec. Rep. 44. Part 29.

Beeton, A. M. 1969. Changes in the environment and biota of the Great Lakes, p. 150-167. In Eu- 
trophication: Causes, consequences, correctives. Natl. Acad. Sci.

Bowers, J. A., AND H. A. VANDERPloeg. 1982. In situ predatory behavior of Mysis relicta in Lake Michigan. Hydrobiologia 93: 121-131.

BradSHAw, A. S. 1964. The crustacean zooplankton picture: Lake Erie 1939-49-59; Cayuga 1910-5161. Int. Ver. Theor. Angew. Limnol. Verh. 15: 700-708.

Brandlova, J., Z. Brandl, and C. H. Fernando. 1972. The Cladocera of Ontario with remarks on some species and distributions. Can. J. Zool. 50: 1373-1403.

Brooks, J. L. 1957. The systematics of North American Daphnia. Mem. Conn. Acad. Arts Sci. 13. $180 \mathrm{p}$.

- 1959. Cladocera, p. 587-656. In W. T. Edmondson [ed.], Freshwater biology, 2nd ed. Wiley.

- 1969. Eutrophication and changes in the composition of zooplankton, p. 236-255. In Eutrophication: Causes, consequences, correctives. Natl. Acad. Sci.

Chandler, D. C. 1940. Limnological studies of western Lake Erie. 1. Plankton and certain physicalchemical data of the Bass Islands region, from September, 1938, to November, 1939. Ohio J. Sci. 40: 291-336.

Chapra, S. C., And A. Robertson. 1977. Great Lakes eutrophication: The effects of point source control of total phosphorus. Science 196: 1448-1450.

Christie, W. J. 1974. Changes in fish species composition of the Great Lakes. J. Fish. Res. Bd. Can. 31: $827-854$.

Crowder, L. B., AND J. J. Magnuson. 1982. Thermal habitat shifts by fishes at the thermocline in Lake Michigan. Can. J. Fish. Aquat. Sci. 39: 10461050.

DamanN, K. E. 1960. Plankton studies of Lake Michigan. 2. Thirty-three years of continuous plankton and coliform bacteria data collected from Lake Michigan at Chicago, Illinois. Trans. Am. Microsc. Soc. 79: 397-404.

DANFORTH, W. F., AND W. GinsBerg. 1980. Recent changes in the phytoplankton of Lake Michigan near Chicago. J. Great Lakes Res. 6: 307-314.

Deevey, E. S., AND G. B. Deevey. 1971. The American species of Eubosmina Seligo (Crustacea, Cladocera). Limnol. Oceanogr. 16: 201-208.

EDDY, S. 1927. The plankton of Lake Michigan. Ill. Nat. Hist. Surv. Bull. 17: 201-208.

Edmondson, W. T., AND A. H. LitT. 1983. Daphnia in Lake Washington. Limnol. Oceanogr. 27: 272293.

Evans, M.S. 1985 . The morphology of Daphnia pulicaria, a species newly dominating the offshore southeastern Lake Michigan summer Daphnia community. Trans. Am. Microsc. Soc. 104: 223231.

231. 1986. Recent major declines in zooplankton populations in the inshore region of Lake Michigan: Probable causes and consequences. Can. J. Fish. Aquat. Sci. 43: in press.

-, AND L. E. FlATH. 1984. Intakes as sampling locations for investigating long-term trends in zoo- plankton populations. Can. J. Fish. Aquat. Sci. 41: 1513-1518.

- , B. E. Hawkins, ANd D. W. Sell. 1980. Seasonal features of zooplankton assemblages in the nearshore area of southeastern Lake Michigan. J. Great Lakes Res. 6: 275-289.

- AND D. W. SEll. 1985. Mesh size and collection characteristics of $50-\mathrm{cm}$ diameter conical plankton nets. Hydrobiologia 122: 97-194.

$\longrightarrow,-$ AND D. I. PAGE. 1982. Zooplankton studies at the Donald C. Cook Nuclear Power Plant: Comparisons of preoperational (1972-1974) and operational (1975-1978) population characteristics. Univ. Mich. Great Lakes Res. Div. Spec. Rep. 89.

Galbraith, M. G., JR. 1967. Size-selective predation on Daphnia by rainbow trout and yellow perch. Trans. Am. Fish. Soc. 96: 1-10.

Gannon, J. E. 1972. A contribution to the ecology of zooplankton Crustacea of Lake Michigan and Green Bay. Ph.D. thesis, Univ. Wisconsin-Madison. $257 \mathrm{p}$.

Goldman, C. R., M. D. Morgan, S. T. Threlkeld, AND N. ANGELI. 1979. A population dynamics analysis of the cladoceran disappearance from Lake Tahoe, California-Nevada. Limnol. Oceanogr. 24: 289-297.

GroGG, C. V. 1977. Morphological variation in the "Pulex" group of the genus Daphnia. M.A. thesis, Ball State Univ. 38 p.

Hatch, R. W., P. M. HaAck, and E. H. Brown, JR. 1981. Estimation of alewife biomass in Lake Michigan, 1967-1978. Trans. Am. Fish. Soc. 110: 575-584.

Hawkins, B. E., And M. S. Evans. 1979. Seasonal cycles of zooplankton biomass in southeastern Lake Michigan. J. Great Lakes Res. 5: 256-263.

JANSSEN, J. 1978. Feeding-behavior repertoire of the alewife, Alosa pseudoharengus, and ciscoes Coregonus hoyi and C. artedii. Can. J. Fish. Aquat. Sci. 35: 249-253.

$\longrightarrow$, AND S. B. BRANDT. 1980. Feeding ecology and vertical migration of adult alewives (Alosa pseudoharengus) in Lake Michigan. Can. J. Fish. Aquat. Sci. 37: 177-184.

JudE, D. J., AND F. J. Tesar. 1985. Recent changes in the forage fish of Lake Michigan. Can. J. Fish. Aquat. Sci. 42: 1154-1157.

— $~$ AND OTHERs. 1979. Inshore Lake Michigan fish populations near the Donald C. Cook Nuclear Power Plant for prcoperational years 1973-1974. Univ. Mich. Great Lakes Res. Div. Spec. Rep. 71.

McNAUGHT, D. C. 1975. A hypothesis to explain the succession from calanoids to cladocerans during eutrophication. Int. Ver. Theor. Angew. Limnol. Verh. 19: 724-731.

Mills, E. L., AND J. L. FonNey. 1983. Impact on Daphnia pulex of young perch in Oneida Lake, New York. Trans. Am. Fish. Soc. 112: 154-161.

Moffet, J. W. 1956. Recent changes in the deepwater fish populations of Lake Michigan. Trans. Am. Fish. Soc. 86: 393-408.

Morsell, J. W., AND C. R. Norden. 1968. Food habits of the alewife Alosa pseudoharengus in Lake 
Michigan. In Proc. 11 th Conf. Great Assoc. Great Lakes Res., p. 96-102. Int. Assoc. Great Lakes Res.

Murtaugh, P. A. 1981a. Size-selective predation on Daphnia by Neomysis mercedis. Ecology 62: 894900.

- $1981 \mathrm{~b}$. Inferring properties of mysid predation from injuries to Daphnia. Limnol. Oceanogr. 26: 811-821.

Patalas, K. 1972. Crustacean zooplankton and eutrophication of the St. Lawrence Great Lakes. J. Fish. Res. Bd. Can. 29: 1451-1462.

Regier, H. A., and W. L. Hartman. 1973. Lake Erie's fish community: 150 years of cultural stress. Science 29: 959-968.

Scavia, D., G. L. Fahnenstiel, M. S. Evans, D. J. JUDE, AND J. T. LEHMAN. 1986. Influence of salmonid predation and weather on long term water quality trends in Lake Michigan. Can. J. Fish. Aquat. Sci. 43: in press.

SCHulze, P. C. 1984. Influences upon the vertical distribution of Lake Michigan microcrustaceans. M.S. thesis, Univ. Wisconsin-Milwaukee. 112 p.

ScotT, W. B., AND E. J. Crossman. 1973. Freshwater fishes of Canada. Bull. Fish. Res. Bd. Can. 184.

Sell, D. W. 1982. Size-frequency estimates of secondary production by Mysis relicta. Hydrobiologia 93: 69-78.

Smith, S. H. 1964. Status of the deepwater cisco populations of Lake Michigan. Trans. Am. Fish. Soc. 93: $155-163$.

1972. Factors in the ecological succession in oligotrophic fish communities in the Laurentian Great Lakes. J. Fish. Res. Bd. Can. 29: 717-730.

Stewart, D. J., J. F. Kitchell, AND L. B. Crowder. 1981. Forage fishes and their salmonid predators in Lake Michigan. Trans. Am. Fish. Soc. 110: 751763.
TESAR, F. J., AND D. J. JudE. 1985. Adult and juvenile fish populations of inshore southeastern Lake Michigan near the Cook Nuclear Power Plant during 1973-1982. Univ. Mich. Great Lakes Res. Div. Spec. Rep. 106.

ThrelKELD, S. T. 1979. The midsummer dynamics of two Daphnia species in Wintergreen Lake, Michigan. Ecology 60: 165-179.

- 1981. The recolonization of Lake Tahoe by Bosmina longirostris: Evaluating the importance of reduced Mysis relicta populations. Limnol. Oceanogr. 26: 433-444.

Wells, L. 1960. Seasonal abundance and vertical movements of planktonic Crustacea in Lake Michigan. Fish. Bull. 60: 343-364.

- 1968. Seasonal depth distribution of fish in southeastern Lake Michigan. Fish. Bull. 67: 1-15. - 1970. Effects of alewife predation on zooplankton populations in Lake Michigan. Limnol. Oceanogr. 15: 556-565.

- 1980. Food of alewives, yellow perch, spottail shiners, trout-perch, and slimy and fourhorn sculpins in southeastern Lake Michigan. U.S. Fish. Wildlife Serv. Tech. Pap. 98.

$\longrightarrow$, AND A. M. BEETON. 1963. Food of the bloater, Coregonus hoyi, in Lake Michigan. Trans. Am. Fish. Soc. 92: 245-255.

- - AND A. L. MCLAIN. 1972. Lake Michigan: Effects of exploitation, introductions, and eutrophication on the salmonid community. J. Fish. Res. Bd. Can. 29: 889-898.

—, AND -. 1973. Lake Michigan: Man's effects on the fish stocks and other biota. Great Lakes Fish. Comm. Tech. Rep. 20.

Submitted: 6 November 1984 Accepted: 18 July 1985 